\title{
The role of public management in Hospital Social Responsibility (HSR) activities in building the image of Sunan Kudus Islamic Hospital
}

\author{
Nurzahroh Lailyah ${ }^{1}$ \\ ${ }^{1}$ Faculty of Economics, Universitas Sunan Muria, Indonesia
}

\begin{abstract}
Purpose - The purpose of this research is to understand the role of Public Relations Management in activities Hospital Social Responsibility (HSR) to improve image of Sunan Kudus Islamic Hospital. This study is also designed to understand the ability of Hospital Social Responsibility (HSR) in bringing benefits to the hospital Islam Sunan Kudus.
\end{abstract}

Method - Primary data were obtained directly from observations and interviews with the Sunan Kudus Islamic Hospital, in this case the Public Relations Management and the community involved in HSR activities. The data analysis technique used several analyzes, namely descriptive, sociological, hostoris, and data validity.

Result - The role of Public Relations in HSR activities can improve image of the Sunan Kudus Islamic Hospital, this is proven with the HSR activities carried out by RSI Sunan Kudus followed by all levels of society in the city Kudus so that through the HSR activity the name RSI Sunan Kudus is known to the wider community and ultimately society who is in the Holy city to entrust his health to Sunan Kudus Islamic Hospital.

Implication - This study can motivate other hospitals to implement HSR (Hospital Social Responsibility), so that a mutual symbiotic relationship can be created between the hospital and the community.

Originality - In other studies only discussing CSR in general, there are no findings regarding HSR, and there is no CSR or HSR aspect in it Islamic perspective, apart from that there are no other benefits seen due to the existence of CSR in the hospital

Keywords: public management, social responsibility, qualitative, organizational image 


\section{Introduction}

One of the activities carried out by Public Relations Management in order to build the image of an organization is by holding CSR (Corporate Social Responsibility) activities. CSR (Corporate Social Responsibility) or social and environmental responsibility in Law No. 40 regarding Limited Liability Companies (UUPT), which requires a company to spend $1 \%$ of its profits on CSR funds. CSR (Corporate Social Responsibility) in recent years has become a byword and prima donna for companies in various countries including Indonesia. Many companies seem to be competing to expose themselves in socially oriented activities, they are active in imagining themselves as companies that care about environmental and social issues, companies usually carry out CSR which refers to sustainable integrated activities.

By creating CSR programs that are relevant, targeted, focused and effective. The goal is that the corporation can be accepted, loved, loved, and lived by stakeholders and achieve lasting economic success. The success of a number of companies such as Sido Muncul, Unilever, Aqua Danone, Djarum, and others have succeeded in making profits and growing their business because they pioneered and innovated in social and environmental responsibility (CSR) activities. This success has inspired many companies and agencies to emulate, one of which is the Sunan Kudus Islamic Hospital.

Currently, people's behavior tends to be very concerned about health, they have flocked to register themselves to take part in the Social Security Administering Body (BPJS), Public Health Insurance (Jamkesmas), and several other health insurance programs. Real circumstances on a daily basis shows that the more sophisticated the tools and the more types of services available will increase the demands of the community for services hospitals, this situation will lead to competition between hospitals. Because of that, business opportunities emerged due to demand from the community, so that now many hospitals have begun to compete to develop products and service quality. To respond to the competitive conditions that 
occur, the Sunan Kudus Islamic Hospital uses a strategy of enhancing its image in the minds of its public.

\section{Literature review}

Research on Corporate Social Responsibility (CSR) is classified as mainstream. It means that many people have researched CSR in the scope of companies and financial institutions. Maybe this happens because students who get CSR material are usually from the Faculty of Economics, Business and Banking, so most of the objects studied are also in companies and financial institutions.

Some of the examples are: (1) The Effect of Corporate Social Responsibility (CSR) and Profitability on Company Value (Mubarok, 2013); (2) The Effect of the Implementation of Corporate Social Responsibility (CSR) on Customer Loyalty in Islamic Financial Institutions (Case Study at the Islamic Financial Institution (LKI) Buana Kartika Mranggen Demak) (Rohmah, 2013); (3) The Influence of Corporate Social Responsibility (CSR) on Public Interest in Saving at BMT Bahtera Pekalongan, (Ma'ruf, 2013); and (4) Analysis of the Effect of Profitability on Firm Value with Corporate Social Responsibility (CSR) as a Moderating Variable (Empirical Study of Companies listed in the Jakarta Islamic Index (JII) on the Indonesia Stock Exchange), (Attamimi, 2015).

Looking at the research history, the authors are interested in researching CSR outside the scope of companies and financial institutions, namely in a hospital agency. As far as the researcher's search, the hospital also has Corporate Social Responsibility (CSR) activities, but the name is not exactly CSR but Hospital Social Responsibility (HSR), which is hospital social responsibility, research on HSR has not been much studied.

One of the writings that the researchers found on related topics was the writing of Nuskha Fariha and Durinda Puspasari Office Administration Education Study Program, Department of Economic Education, State University of Surabaya entitled "The Role of Public 
Realtions in Corporate Social Responsibility (CSR) Activities to Improve Image Fathma Medika Gresik Hospital" (Fariha, 2015).

The study itself only discussing CSR in general, there are no findings regarding HSR, and there is no CSR or HSR aspect from an

JIEMB | 98 Islamic perspective, besides that there are also no other benefits that are seen due to the existence of CSR at Fathma Medika Gresik Hospital.

The author will also reveal the secrets of Islam behind the HSR at the Sunan Kudus Islamic Hospital, examine the role of Public Relations Management in its HSR activities and find out the role of HSR in building the image of the Sunan Kudus Islamic Hospital. As well as reviewing the benefits obtained from the increasing image of the Sunan Kudus Islamic Hospital. From the formulation of the problem, the objective of this research is finding the role of public relations management in in hospital social responsibility (HSR) activities in building the image of Sunan Kudus Islamic Hospital.

\section{Methodology}

The data used in this research are primary data and secondary data. Primary data were obtained directly from observations and interviews with the Sunan Kudus Islamic Hospital, in this case the Public Relations Management and the community involved in CSR activities. While secondary data is obtained from literature, journals, or data related to the research objectives, namely knowing the role of Public Relations Management in HSR activities in building the image of the Sunan Kudus Islamic Hospital, and knowing the ability of HSR itself in bringing benefits to the Sunan Kudus Islamic Hospital.

\section{Data analysis techniques}

Descriptive

In this case, the object of research is the Sunan Kudus Islamic Hospital. The author will describe the role of Public Relations Management in Hospital Social Responsibility (HSR) activities in building the image of the Sunan Kudus Islamic Hospital. 
Sociology

Describes the situation of the relationship between the Sunan Kudus Islamic Hospital with the community and the environment around the hospital.

Historical

Describing the history of the establishment of the Sunan Kudus Islamic Hospital, then the development and successes achieved by the Sunan Kudus Islamic Hospital, as well as the activities carried out by the Sunan Kudus Islamic Hospital.

Data Validity Method

Testing the validity of the data carried out in the study is to use triangulation. "Triangulation is a data validity checking technique that utilizes something other than the data for checking purposes or as a comparison to the data". In this study, the triangulation model used was Source triangulation. Source triangulation is the step of checking data obtained from informants by asking the informant for the correctness of the informant's data from one informant.

\section{Results and discussion}

The role of public relations management in building the image of the Sunan Kudus Islamic Hospital

Restricting the problem

Based on the results of an interview with the assistant managers of the hospital, they stated the same information that before the HSR activity process is carried out, Public Relations has the role of accommodating ideas from all employees then the idea is turned into a social activity which the activity is meant for introduce potential hospitals to be introduced to the public. Thus creating external HSR activities such as: free cataract surgery, natural disaster social services, health counseling, for qurban meat for the day of Eid fitri, donation for orphans, mass circumcision, and grants benefits.

For example, Free Cataract Surgery, The limitation of the problem are:

1. Problems faced by the community around the hospital located (researching about desired needs and interests public) 
One of the problems faced the community of Kudus and its surroundings namely the number of people especially those have reached old age experiencing cataracts in his eyes, but they tended to let his eyes be like that. This is due to economic conditions which doesn't allow it to do cataract surgery at a reasonable cost expensive.

2. Search and get data in order to find out how the situation and conditions contained in public; From the situation and condition of the problem faced by society related to the number of eye cataract sufferers, Public Relations found 37 eye cataract sufferers on at that time.

3. Find and determine who is be the target of its activities;

The target in the activity Islamic Hospital free cataract surgery Sunan Kudus is a community of the Kudus area who suffer from eye cataract.

\section{Planning and Programming}

Based on the results of the interview, it also can be concluded that public relations plays the role of party designing the process communications that will be used during implementation HSR activities. Communication carried out with parties internal and external agencies. Public relations also plays a role to find which parties will be cooperate in HSR activities. Public relations acts as a mediator and provides solutions to the problem of differences in perceptions that arise between individuals. Solutions are provided by means of discussions or meetings so that communication problems can be resolved resolved properly so that problems do not arise recently faced.

For Example, Natural Disaster Social Service:

In this natural disaster social service activity, Public Relations assisted by Management Assistant Marketing Mr. Erwin Kuncoro and the spiritual activists of Hospital Sunan Kudus Islamic. As for the help that is on At that time, the donations were basic necessities, baby milk, bread dry, baby diapers, and medication. For help The budget provided is 5 million taken from HSR funds Sunan Kudus Islamic Hospital. 


\section{Act and Communicate}

The hospital representations also stated the same information that public relations as the party that moves or acts so that the HSR activities of the Sunan Kudus Islamic Hospital can be carried out well according to planning and predefined programming. PR as well as parties who know about the implementation of activities HSR so that $\mathrm{PR}$ has a role to spread information regarding the implementation of HSR activities with using direct communication media and media electronic.

Direct communication carried out with how to provide information about the existence of HSR activities that will be carried out by the Sunan Islamic Hospital Holy through spreading information by word of mouth. Then indirect communication media were carried out through electronic media. PR uses the media electronic social networks like Facebook, as well enter HSR news through a website that can accessed directly by all levels of society. The Facebook address for the Sunan Islamic Hospital Kudus, namely "Information Regarding YAKIS - ISY" or can directly visit the hospital's website address Islam Sunan Kudus that can be accessed by all people: http://www.rsisunankudus.com/.

\section{Program Evaluation}

In this final stage, Home Public Relations Management Sunan Kudus Islamic pain reassess the extent HSR activities are acceptable. Evaluation carried out Public Relations Management by paying attention to the response the community around the Sunan Kudus Islamic Hospital. This evaluation is important in order to formulate a new step or policy for Public Relation activities Sunan Kudus Islamic pain. Knowing the mechanism of assessment to RSI Sunan Kudus, namely by doing interviews with four local residents concerned their opinion about the HSR activities being held RSI Sunan Kudus. The local residents stated that:

1. Service quality is very good, religious, polite, and friendly to all inpatients and caregivers Street.

2. Sunan Kudus Islamic Hospital has many contribute to the surrounding community, a lot help and help the difficulties of local residents especially in the health sector. Islamic Hospital Sunan Kudus also cares about the environment the 
surrounding community, by holding activities such as: provision of health education about DHF, Hypertension, TB (Tuberculosis), procurement of free mass circumcision, free cataract surgery, compensation for orphans, and so on.

JIEMB $\mid 102$

3. The community is not bothered by the existence of the Sunan Kudus Islamic Hospital rather feel good, they say that with so many social activities involving the outside community makes them capable establish a relationship like close relatives. So that when they were sick, then now they have entrusted his health to the Hospital Islam Sunan Kudus

From the discussion above, based on community assessment data via Facebook and results direct interview, it can be concluded that the role Public Relations in HSR (Hospital Social Responsibility) activities able to build the image of the Sunan Kudus Islamic Hospital, this is evidenced by the HSR activities carried out by the house Sunan Kudus Islamic Pain was followed by many people which is in the city of Kudus so that through HSR activities that is the good name of the Sunan Kudus Islamic Hospital increasingly known to the wider community, if this HSR activity is carried out with commitment and sincerity, the image of the Hospital Islam Sunan Kudus will continue to increase. With the formation of a good image, it will make the public sure of the existence or existence of the Islamic Hospital Sunan Kudus and the community also entrusted it his health at the Sunan Kudus Islamic Hospital.

\section{HSR's ability to bring benefits to Sunan Kudus Islamic Hospital}

Based on the results of research on point $A$ which contains that "The role of Public Relations in Social Hospital activities Responsibility (HSR) is able to build the image of the Hospital Islam Sunan Kudus, as evidenced by HSR activities conducted by the Sunan Kudus Islamic Hospital followed by many people in the city of Kudus so that through HSR activities are a good name for the Sunan Islamic Hospital Kudus is increasingly known to the wider community, if the HSR activities this is done with commitment and sincerity hence the image The Sunan Kudus Islamic Hospital will continue to increase. 
With the formation of a good image, it will create the public believes in the existence or existence of the Hospital Islam Sunan Kudus and the community also entrust it his health at the Sunan Kudus Islamic Hospital ". Result the research is true, researcher obtain data on the number of hospital patients per year can corroborate these results. Based on total data hospital patients, both inpatients and inpatients the road shows a significant change after the implementation of the HSR activities. So that it can be assessed that HSR activities are able to build the image of the Hospital Islam Sunan Kudus. The following is the data obtained from Management Assistant Medical Records.

From the data on the number of patients at the Sunan Islamic Hospital Kudus taken in the last 6 (six) years before they existed HSR (Hospital Social Responsibility), the trend can be seen in Table 1 and Figure 1.

From the line diagram in Figure 1, it can be seen that the number patients at the Sunan Kudus Islamic Hospital before the HSR experiencing irregular fluctuations, both patients are hospitalized both inpatients and outpatients. And not yet indicates a significant increase in the number of patients. For the number of hospitalized patients from 2006 - 2011 only moving at 5500 - 6500 per year.

Meanwhile, for the number of outpatients in 2006 - 2009 only moves in the numbers $9000-9800$, although it can be admitted the number exceeds the number of hospitalized patients, however if seen the development per year from 2006-2011, only in 2010 has it increased quite appreciably, but in 2011 it again experienced drop.

From the data on the number of patients at the Sunan Islamic Hospital Kudus, taken 5 (five) years after the HSR was established (Hospital Social Responsibility) diagrams can be seen in Table 2 and

Table 1. Number of Patients in Sunan Kudus Islamic Hospital before HSR

\begin{tabular}{lll}
\hline Year & Inpatient & Outpatient \\
\hline 2006 & 6019 & 9525 \\
2007 & 6087 & 9756 \\
2008 & 5848 & 9286 \\
2009 & 5993 & 9432 \\
2010 & 6122 & 10104 \\
2011 & 5760 & 9032 \\
\hline
\end{tabular}




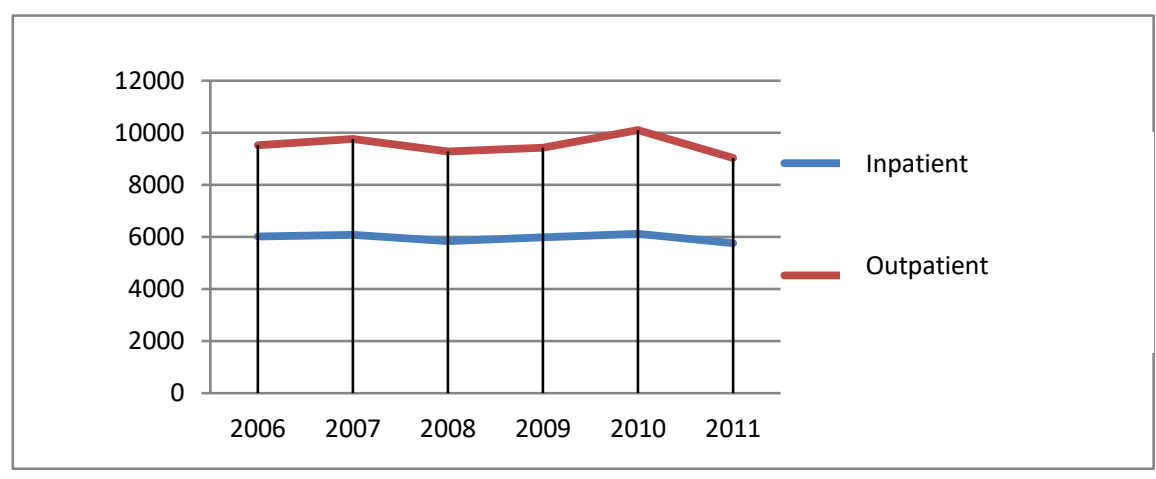

Figure 1. Number of Patients in Sunan Kudus Islamic Hospital before HSR

Figure 2. From the line diagram in Figure 2, it can be read that the number Sunan Kudus Islamic Hospital patients after HSR has increased the number of patients continuously over years 2012 2016, this increase shows that there is a relationship closely between HSR and the increasing number of patients on Sunan Kudus Islamic Hospital, both inpatients, as well as outpatients. The combined data from 2006-2016 shows a comparison of pre-HSR and post-HSR program at Sunan Kudus Islamic Hospital in 2006-2011.

The comparison between 2006-2011 is clear before there was HSR with the number of Islamic Hospital patients Sunan Kudus in 20122016 after the HSR. The increase in the number of patients following HSR will have an impact good for the hospital, namely the increase in profit. So far, that has been the goal of a company established is to obtain maximum profit and build a corporate image that will ensure the company's sustainable growth (sustainability) if the company pays attention to aspects economy, social and environment.

Table 2. Number of patients at Sunan Kudus Islamic Hospital after HSR

\begin{tabular}{lll}
\hline Year & Inpatient & Outpatient \\
\hline 2012 & 10393 & 15016 \\
2013 & 12071 & 18281 \\
2014 & 12420 & 20585 \\
2015 & 12682 & 21472 \\
2016 & 13505 & 25066 \\
\hline
\end{tabular}




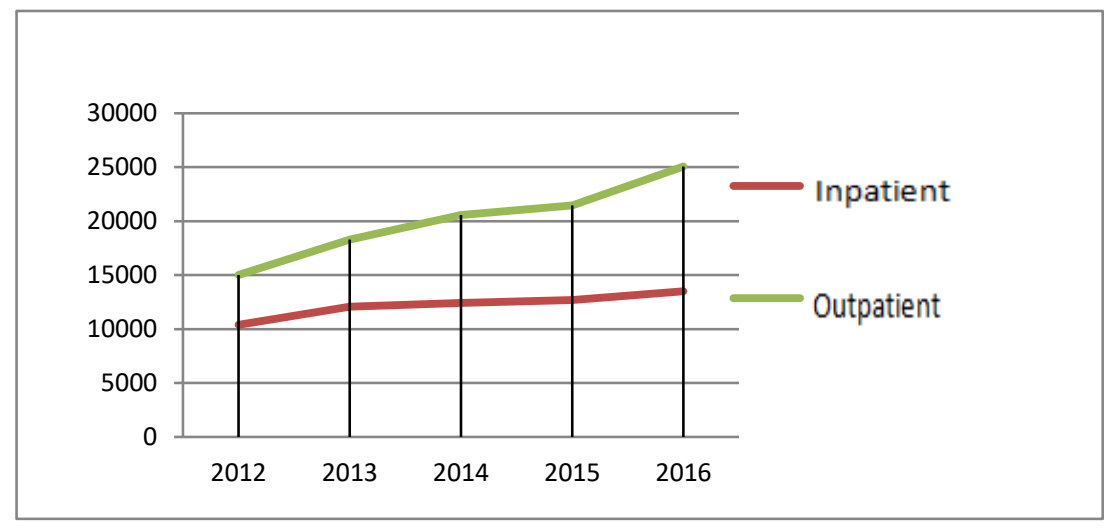

JIEMB | 105

Figure 2. Number of Patients in Sunan Kudus Islamic Hospital after HSR

Society too already smart in assessing how a contribution the company towards the interests of society and the environment the surroundings. So far, HSR has been identified with how much the amount of money spent by the company. To build the image of the Sunan Islamic Hospital Kudus. Researchers tend to be aggressive with HSR activities external, arguing that external HSR activities are activities that are intended for outsiders hospital, or in this case, the community of the Kudus area and its surroundings.

In carrying out its HSR programs, The Sunan Kudus Islamic Hospital is quite profitable for owners and shareholders. However, reversed sacrifice, the Sunan Kudus Islamic Hospital able to reap multiple benefits. This is exactly the cost-benefit theory where the costs incurred will be bring benefits.

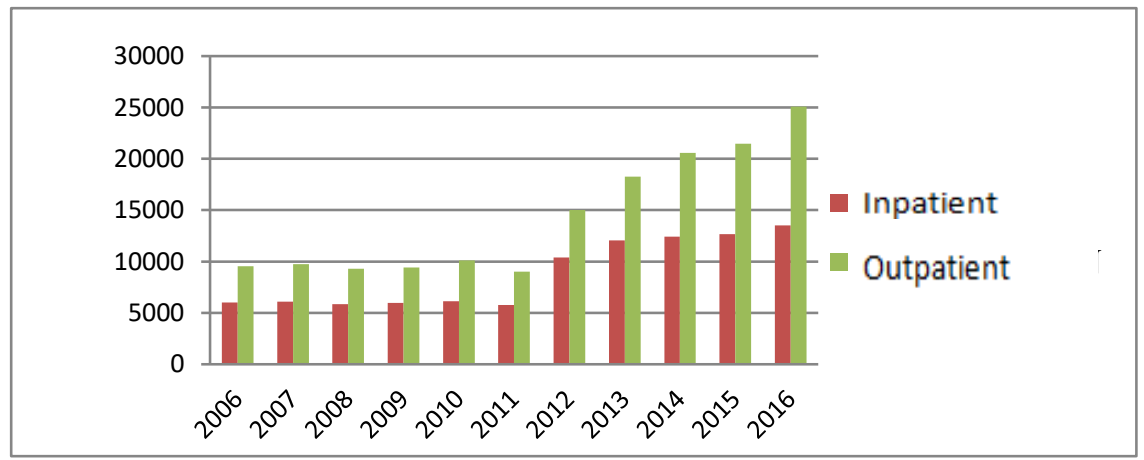

Figure 2. Number of Patients in Sunan Kudus Islamic Hospital after HSR 
These benefits are increased reputation and good name of the hospital, increased loyalty employees, investors, creditors, and customers. A number these benefits, in the end will bring benefits economy for the Sunan Kudus Islamic Hospital. As for example, that is, the number of patients increases so that profits also increased.

The benefits are almost as written by Kottler and Lee in their book entitled "Corporate Social Responsibility: Doing The Most Good For Your Company and Your Cause "there are six benefits of business that can be obtained by companies that carry out CSR, namely: (1) increase the influence and image of the company; (2) increase market share and sales; (3) strengthen brand positioning; (4) increase the company's capabilities to earn, motivate, and retain loyalty of workers; (5) lowering operating costs; (6) increase the attractiveness of investors, creditors and analysts finance.

Although HSR is taken from a western term, namely Hospital Social Responsibility which means responsibility social, but it turns out that HSR also has Islamic values therein, HSR is seen as a charitable act bring blessings or abundant profits for the house Sunan Kudus Islamic pain. If the hospital puts aside funds to implement HSR consistently and on a basis sincere intention is an investment that will pay off profit at a later date. Although at first it felt like heavy loads, but if done consistently (istiqomah) and sincere (sincere), the HSR will change become a profitable burden. In the Qur'an's Surah Al-Baqarah verse 261:

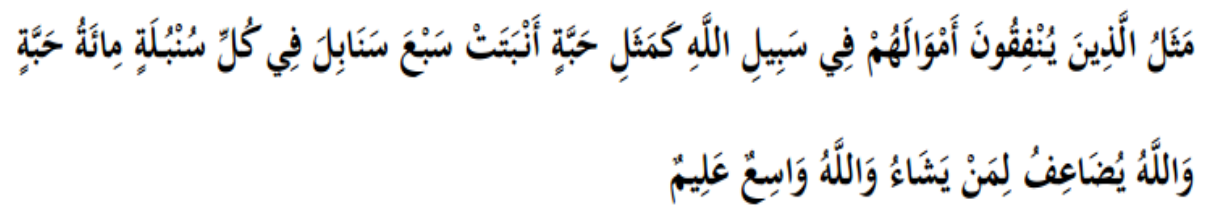

"The parable of the man who spent his wealth in the way of Allah like a seed that grows seven strung, on each stalk there are a hundred seeds. Allah will multiply for whom he wills, and Allah Most Broad, All-Knowing".

In the hadith of Rosulullah SAW it is also explained, namely, 


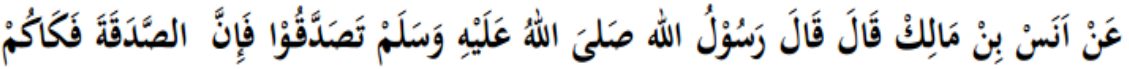

$$
\text { النًّار (رواه الدارقطنى والطبرانى وأبو نعيم والبيهقى وابن عساكر) }
$$

"From Anas bin Malik said, Rosulullah SAW said: give alms, because actually charity is can prevent from hell fire".

The verses and hadiths above, have something to do with HSR conducted by the Sunan Kudus Islamic Hospital, where the HSR activities are human-based, namely at social sphere. Since the implementation of the HSR, namely 2012 The Sunan Kudus Islamic Hospital has experienced developments. The development of the hospital is shown by the existence significant changes between 2006-2011 (the last six years prior to the existence of HSR) with 2012-2016 (the last five years after the HSR was introduced).

Apart from that there is also other evidence that shows the Sunan Islamic Hospital Kudus experienced development, Sunan Kudus Islamic Hospital constructed a new building with a design modern with an Islamic impression, where is this development starting in 2015 , which is planned to be completed early in the year 2018.

Based on an interview with the Plan Manager Dr. Development $\mathrm{Hj}$. Fauziyah obtained information that an increasing number of hospital patients are making a profit The Sunan Kudus Islamic Hospital has also increased, he could not tell how much profit obtained by the hospital, it is just that he gave information about the things behind the development it is the lack of hospital room capacity due to the increasing number of patients, due to home profits the pain also increased, so it was decided to do additions to new buildings that are bigger and more modern too.

Dr. Hj. Fauziyah also said that "This development happened thanks to the role of PR. Since Public Relations implements its HSR activity, Citra Hospital Islam of Sunan Kudus is increasingly known throughout all layers the community of the Kudus area and its surroundings. So it's getting many people also entrust their health to the Sunan Kudus Islamic Hospital". 


\section{Conclusion}

Based on the results of the analysis in chapter iv, it is capable answer two problem formulations in this thesis research. Below are the answers to two problem formulations.

The role of Public Relations in HSR activities can improve image of the Sunan Kudus Islamic Hospital, this is proven with HSR activities carried out by RSI Sunan Kudus followed by all levels of society in the city Kudus so that through the HSR activity the name RSI Sunan Kudus was known to the wider community and ultimately the public those in the Holy city entrusted their health to Sunan Kudus Islamic Hospital.

Besides HSR being able to improve the image of RSI Sunan Kudus, it turns out that HSR is also able to bring other benefits, benefits which was obtained by RSI Sunan Kudus thanks to the role of Public Relations in its HSR activities, namely: increased employee loyalty thanks to internal HSR activities, and the number of patients inpatient and outpatient services have increased blessings external HSR activities.

\section{References}

Ahmad Syakir, Syaikh. Mukhtashar Tafsir Ibnu Katsir, Jakarta : Darus Sunnah Press, Jilid 1, Cet. 2. 2014.

Amir, M. Taufiq. Manajemen Strategik Konsep dan Aplikasi, Jakarta : P.T. Rajagrafindo Persada, 2012.

Ariyani, "Pengaruh Pengungkapan Corporate Social Responsibility terhadap Profitabilitas dan Reaksi Pasar: Studi Empiris pada Emiten Manufaktur di Bursa Efek Indonesia (BEI)", Jurnal Studi Akuntansi Fakultas Ekonomi Unika Soegijapranata Semarang, 2008.

Armen, Fakhni \& Viviyanti Azwar, Dasar-Dasar Manajemen Keuangan Rumah

Sakit, Yogyakarta : Gosyen Publishing, 2013.

Astuti, "Relevansi Nilai Laporan Keuangan untuk Investor Pasar Saham pada Perusahaan yang Peduli dan Kurang Peduli Corporate Sosial Responsibility (CSR)", Jurnal Studi Akuntansi Fakultas Ekonomi Unika Soegijapranata Semarang, 2010. 
Attamimi, N. (2015). Analisis pengaruh profitabilitas terhadap nilai perusahaan dengan corporate social responsibility sebagai variabel moderating (studi empiris pada perusahaan yang tercatat dalam Jakarta Islamic Index (JII) di Bursa Efek Indonesia) (Doctoral dissertation, UIN Walisongo).

Butterick, Keith . Pengantar Public Relations : Teori dan Praktik, diterjemahkan dari buku aslinya : Introduction Public Relations: Theory and Practic oleh Nurul Hasfi, Jakarta : PT RajaGrafindo Persada, cetakan ke-1, Maret 2012.

Danandjaja, Peranan HuMas Dalam Perusahaan, Yogyakarta: Graha IImu, 2011.

Fariha, N. (2015). Peran public relations dalam kegiatan csr untuk meningkatkan citra rumah sakit fathma medika gresik. Jurnal Pendidikan Administrasi Perkantoran (JPAP), 3(3).

Fariha, Nuskha \& Durinda Puspasari, "Peran Public Relations dalam Kegiatan CSR untuk Meningkatkan Citra Rumah Sakit Fathma Medika Gresik", Jurnal Studi Pendidikan Administrasi Perkantoran, Jurusan Pendidikan Ekonomi Universitas Negeri Surabaya, 2015.

Interview with Ass. Manaj. Humas \& Hukum RSI Sunan Kudus, Ibu Diah Setyartuti, 2017.

Interview with Bpk. Ikhwani, Wakil Ass. Manaj. Diklat yang mewakili ibu. $\mathrm{Hj}$. Arum, 2017.

Interview with ibu Susilowati S.Kep, Ass. Humas RSI Sunan Kudus, 2017.

Interview with Manajer Rencana Pembangunan Dr. Hj. Fauziyah, 2017.

Kholisoh, Nur. Universitas Mercu Buana, Yenita, Universitas Tarumanegara, "Strategi Komunikasi Public Relations dan Citra Positif Organisasi (Kasus Public Relations Rumah Sakit "X" di Jakarta)", Jurnal Studi IImu Komunikasi, Volume 13, Nomor 3, September - Desember 2015.

Lako, Andreas. Dekonstruksi CSR \& Reformasi Paradigma Bisnis \& Akuntansi, Jakarta : Erlangga, 2011.

Ma'ruf, M. R. (2013). Pengaruh corporate social responsibility (CSR) terhadap minat menabung di BMT Bahtera Pekalongan (Doctoral dissertation, IAIN Walisongo).

Maulin Purwaningwulan, Melly. "Public Relations dan Manajemen Krisis", Jurnal Program Studi IImu Komunikasi, Fakultas IImu Sosial dan IImu Politik, Universitas Komputer Indonesia, Vol. 11, No. 2.

Mira Vegawati, Silvania., Srikandi Kumadji dan Dahlan Fanani, "Pengaruh Program Corporate Social Responsibility (CSR) Terhadap Citra 
Perusahaan (Survey Pada Warga di Desa Sidodadi Kelurahan Kalirejo Kecamatan Lawang Kabupaten Malang)", Jurnal Administrasi Bisnis (JAB), Universitas Brawijaya Malang, Vol. 20, No. 1, Maret 2015.

Monica, "Pengaruh Corporate Social Responsibility (CSR) terhadap Economic Value Added (EVA) dan Market Value Added (MVA): Studi Empiris pada Emiten Manufactur di Bursa Efek Indonesia (BEI)", Jurnal Studi Akuntansi Fakultas Ekonomi Unika Soegijapranata Semarang, 2010.

Mubarok, F. K. (2013). Pengaruh Corporate Social Responsibility dan Profitabilitas terhadap Nilai Perusahaan (Studi pada Perusahaan yang Listing di Jakarta Islamic Index Tahun 2009-2011) (Doctoral dissertation, IAIN Walisongo).

Puspitasari, “Reaksi Pasar terhadap Publikasi Informasi Tanggung Jawab Sosial dan Lingkungan (CSR) yang Memiliki Luas Pengungkapan Berbeda Dalam Laporan Keuangan: Studi pada Perusahaan Manufaktur yang Terdaftar di BEl", Jurnal Studi Akuntansi Fakultas Ekonomi Unika Semarang, 2010.

Rohmah, A. A. (2013). Pengaruh penerapan corporate social responsibility (CSR) terhadap loyalitas nasabah lembaga keuangan Islam (studi pada nasabah LKI Buana Kartika Mranggen) (Doctoral dissertation, IAIN Walisongo).

Rusdianto, Ujang. CSR Communications A Framwork For PR Practitioners, Yogyakarta: Graha Ilmu, Edisi Pertama, Cetakan Pertama, 2013.

Rusmawati,"Peran Public Communication PT. Kaltim Prima Coal dalam Melaksanakan Program Corporate Social Responsibility di SangattaKutai Timur", Jurnal Studi IImu Komunikasi, Fakultas IImu Sosial dan IImu Politik Universitas Mulawarman, 2013.

Suhandang, Kustadi. Public Relations Perusahaan, Bandung : PT Karya Nusantara, 1973.

Ulum, Bahrul., Zainul Arifin dan Dahlan Fanani, "Pengaruh Corporate Social Responsibility Terhadap Citra (Survey pada Warga Sekitar PT. Sasa Inti Gending-Probolinggo)", Jurnal Administrasi Bisnis (JAB), Universitas Brawijaya Malang, Vol. 8, No. 1, Februari 2014.

Utomo, Pudji. "Strategi Public Relations dalam Pelayanan Informasi", Jurnal Komunikologi, Fakultas IImu Komunikasi, Universitas INDONUSA Esa unggul Jakarta, Vol. 2, No. 1, Maret 2005.

Wilardjo, Setia Budhi. "Corporate Social Responsibility", Jurnal Studi Ekonomi Universitas Muhammadiyah Semarang, 2008. 
The role of public management in Hospital Social Responsibility....

Yenti, Anofrida . "Pengaruh Penerapan Program Corporate Social Responsibility Terhadap Citra Perusahaan PT. Semen Padang (Studi Kasus Masyarakat Kecamatan Lubuk Kilangan Padang)", Jurnal Studi Ekonomi, Universitas Negeri Padang.

Zain, Curratie. "Collaboration Strategy dalam Implementasi CSR: Studi Kasus Aqua Danone Klaten", Jurnal Departemen Hubungan Internasional Universitas Airlangga, 2015. 
Nurzahroh Lailyah

JIEMB | 112

Journal of Islamic Economics, Management, and Business-Vol 2. No.1 (2020) 
